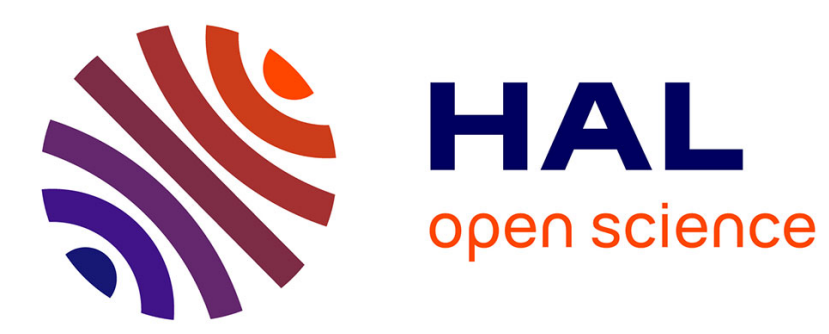

\title{
Solar thermal active systems : from closed form models to simple sizing rules for collector circuits
}

\author{
Bernard Bourges, Jérome Adnot
}

\section{To cite this version:}

Bernard Bourges, Jérome Adnot. Solar thermal active systems: from closed form models to simple sizing rules for collector circuits. BLOSS, W.H. and PFISTERER, F. Advances In Solar Energy Technology, Pergamon, pp.1172 - 1176, 1988, 978-0-08-034315-0. 10.1016/B978-0-08-034315-0.502275. hal-00949139

\section{HAL Id: hal-00949139 \\ https://hal.science/hal-00949139}

Submitted on 23 May 2014

HAL is a multi-disciplinary open access archive for the deposit and dissemination of scientific research documents, whether they are published or not. The documents may come from teaching and research institutions in France or abroad, or from public or private research centers.
L'archive ouverte pluridisciplinaire HAL, est destinée au dépôt et à la diffusion de documents scientifiques de niveau recherche, publiés ou non, émanant des établissements d'enseignement et de recherche français ou étrangers, des laboratoires publics ou privés. 
SOLAR THERMAL ACTIVE SYSTEMS: FROM CLOSED FORM MODELS

TO SIMPLE SIZING RULES FOR COLLECTOR CIRCUITS

Bernard BOURGES, Consultant

6. rue de 1'Armor, 35760' St-Grégoire (France)

Jérome ADNOT, Centre d'Energétique, Ecole des Mines

60, Bd St-Michel 75006 Paris (France)

\section{ABSTRACT}

A simple closed-form model of thermal solar active systens (Space or Water heating) is presented. It deals both with fully-mixed storage and perfectly stratified storage and enables a better understanding of physical phenomena occurring within the system (e.g. low collector flow-rate effects). Direct application of this model makes it possible to establish partial sizing rules for the system components: storage capacity, storage insulation, pipe insulation, heat-exchanger area, collector flow-rate.

\section{KEYWORDS}

Solar heating; solar Donestic Hot Water; design; closed-form model; stratification; solar collector; storage; heat-exchanger; pipe loss.

\section{INTRODUCTION}

Active solar thermal system operation can still be improved; this involves physical phenomena introduced by "system effects" which are as yet insufficiently known. The so-called "low collector flow-rate" discussion over these last few years (Van Koppen, 1979; Fanney and Klein, 1986; tollands and co-w. , logs pointed out this fact. Detailed simulation program This concens besis closed fike stratio provide essential infonation. this concerns basis phenoma, like straticication, but has also practical brief presentation of this type of sion applications.

\section{CLOSED-FORM MODEL}

This model has been developed by Bourges and Adnot (1986). It is based on a number of usual linear thermal assumptions for each component: solar collector, heat-exchanger, storage heat loss, etc. The space-averaged storage temperature $T$ is governed by the differential equation

$$
M c d T / d t=A F_{r}{ }^{\prime}\left(n_{0} I-U_{1}\left(T_{b}-T_{a}\right)\right)-A_{s} U_{S}\left(T-T_{e}\right)-L
$$

The right-hand side of this equation includes three terms: collector energy output (controlled and therefore never negative); storage heat loss; energy taken from storage to meet the load. In the fully-mixed storage case, the storage is storage is perfectly stratified, To may be computed during one storage cycle ray the intial condins within the tank. The energy taken from the store (Directly from the store or at collector outlet), but it is generally characterized by a draw-off flow-rate, m2.

The solution of eqn (1) in the "mixed case" involves the "systen heat store storage correction factor", introduced by phillips (1981). This term is limited storage simple case (constant draw-off, no losses), it takes the form

$$
G_{c s t}=\left(1-\operatorname{EXP}\left(-A F_{r}^{\prime} U_{1} t_{d} / M c\right)\right) . M c /\left(A F_{r}^{\prime} U_{1} t_{d}\right)
$$

This solution may be generalized to provide a stratified system for which an equivalent mixed system may be defined by introducing two stratification coefficients $\mathrm{Kl}$ and $\mathrm{K} 2$ (Bourges and Adnot, 1986) (Table 1).

The first one applies as a multiplicative factor both to $\mathrm{Fr}^{\prime}$ and $\mathrm{m} 2$; the second one to storage heat loss. The following basic assumption is required: the storage water passes through the collector at least once during collector operating time (one storage cycle at least). Theoretically a whole number of cycles or passes is needed, but that has no effect for more than two cycles.

Table I Stratification coefficients vs $a z=\left(I-A F_{r}{ }^{\prime} U_{1} / m_{1} c_{1}\right)\left(1-m_{2} / m_{1}\right)$

\begin{tabular}{cccccc}
\multicolumn{5}{c}{$\mathrm{A}_{\mathrm{s}} \mathrm{U}_{\mathrm{S}} / \mathrm{m}_{1} \mathrm{c}_{1} \mathrm{z}=0$} \\
\hline $\mathrm{az}$ & 1.0 & 0.8 & 0.6 & 0.4 & 0.2 \\
\hline $\mathrm{K}_{1}$ & 1.00 & 1.1 .2 & 1.28 & 1.53 & 2.02 \\
$\mathrm{~K}_{2}$ & 1.00 & 1.00 & 1.02 & 1.07 & 1.20
\end{tabular}

$$
\begin{array}{ccccc}
\multicolumn{4}{c}{\mathrm{A}_{\mathrm{S}} \mathrm{U}_{\mathrm{S}} / \mathrm{m}_{1} \mathrm{c}_{1} \mathrm{z}=0.25} \\
\hline 1.0 & 0.8 & 0.6 & 0.4 & 0.2 \\
\hline 1.00 & 1.11 & 1.26 & 1.50 & 1.95 \\
1.00 & 1.00 & 1.02 & 1.07 & 1.20
\end{array}
$$

\section{STRATTFTCAmTON EFFECTS}

It is well known that for thermosyphon or direct systems the collector flow-rate has no effect on daily efficiency if no draw-off occurs during the operating period (Gordon and Zarmi, 1981): the stratification coefficient $\mathrm{Kl}$ exactly compensates the decrease in the heat-removal factor Fr. If water is drawne the tank during the day, an optimal collector flow-rate is observed; it corresponds to a single-pass system (one storage cycle during This result can be illustrated with the solution to an i (constant irradiance) (an bo lon 1 (constant performace pate. 
Fig. 1: Daily system efficiency of a stration of number of cycles (direct syst.

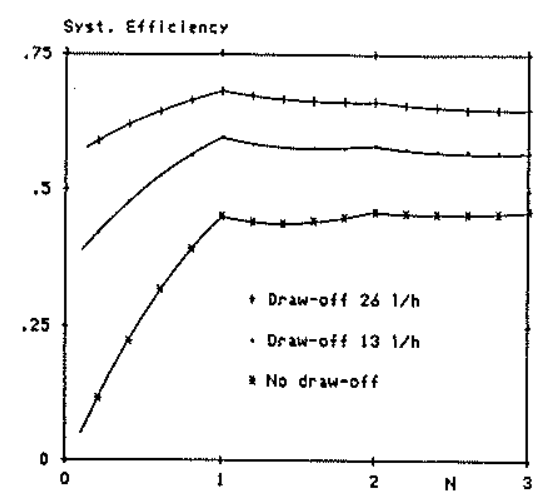

STORAGE SIZING: MAXIMAL DAILY TEMPERATURE

The system heat storage factor (eqn 2) makes it possible to calculate the storage energy content at the end of the daily collecting period, and therefore the storage temperature if the solar irradiance is constant (no draw-ofr). It has been generalized (Bourges and Adnot, 1986) to cover other irradiance profiles, like a sine-shaped radiation (more realistic). Values although the operating time is shorter, but differences are negligible as long as the operating period is less the but aifferes factor makes it possible to compute the maximal ctorage tenperature for given day with maximal in temperature T0

$$
\mathrm{E}_{\mathrm{S}}=A \mathrm{~F}_{\mathrm{r}}^{\prime} G \mathrm{n}_{0} \emptyset \mathrm{H}_{\mathrm{t}}
$$

Daily Utilizability, $\emptyset$, is computed at the threshold irradiance defined by initial temperature To.

Table 2 Systen heat storage correction factor vs $x=M C /\left(A F_{r} U_{l} t_{d}\right)$

\begin{tabular}{lllllllll}
\hline $\mathrm{x}$ & 0.20 & 0.50 & 0.75 & 1.00 & 1.50 & 2.00 & 3.00 & 5.00 \\
\hline $\mathrm{G}_{\mathrm{sin}}$ & .271 & .493 & .596 & .664 & .749 & .800 & .857 & .910 \\
$\mathrm{G}_{\mathrm{cst}}^{\mathrm{s}}$ & .199 & .432 & .552 & .632 & .730 & .787 & .850 & .906 \\
\hline
\end{tabular}

STORAGE AND PIPE INSULATION

Pipe and duct heat loss can be integrated in the collector characteristics, as proposed by Beckman (Duffie and Beckman, 1980). These formulas can be slightly modified and generalized by considering inlet and outlet pipes (with respective heat loss coefficients: AinUin, Aoutlout) as heat-exchangers (with their own effectiveness). The modified collector loop
characteristics can then be computed as follows

$$
\mathrm{U}_{1}^{*}=\mathrm{U}_{1}+\left(\mathrm{A}_{\text {in }} \mathrm{U}_{\text {in }}+\mathrm{A}_{\text {out }} \mathrm{U}_{\text {out }}\right) / \mathrm{A}
$$

$$
\mathrm{n}_{0}{ }^{*}=\mathrm{n}_{0} \cdot \operatorname{Exp}\left(-A_{\text {out }} \mathrm{U}_{\text {out }} / \mathrm{m}_{0} \mathrm{c}_{0}\right) \cdot \mathrm{F}_{\mathrm{r}} / \mathrm{F}_{\mathrm{x}}{ }^{*}
$$

The effect of pipe heat loss on long-term system performance may be approximated for a given typical day by eqn 3. It is more important for stratified systems, with low collector flo

As stated by table I, storage heat loss is slightly enhanced by stratification (aue to higher temperatures obtained with

\section{HEAT-EXCHANGER SIZING}

Most of the systems include an external or immersed heat-exchanger between collector and storage. Sizing of the heat-exchanger is somewhat critical. This theory provides some useful information.

Immersed coils generally imply a mixed tank. Losses caused by the efficjency factor $\mathrm{Fr}^{\prime}$ whith the limiting value for an infinite flow-rate

$$
F_{x}=1 /\left(1+A_{1} / A_{e} U_{e}\right)
$$

Its variations are represented by fig.2: The lesser of the losses in output from the flow-rate $(F x)$ and the heat-exchanger $(F x)$ may be disregarded in practice. At a given flow-rate, a minimum heat-exchanger size is needed but a precise heat transfer coefficient computation is not required. This is an interesting result, if we keep in mind the poor accuracy of such heat-transfer calculation (Feiereisen, 1982).

Fig.2: Collector heat-exchanger correction factor for immersed coils

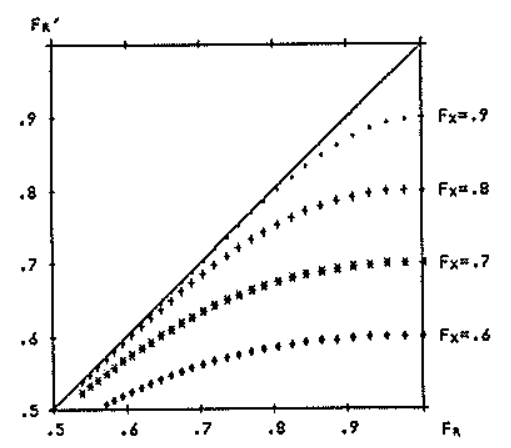

External heat-exchangers are concerned both with F'r (like immersed coils) and stratification coefficients. The parameter to be considered is their respective product. Fig. 3 shows that for a given primary loop (collector heat-exch.) there is an optimal flow-rate ratio on both sides of the heat-exchanger for which $\mathrm{Fx}$ (egn 6 ) is determined again. As for direct systems, flow-rates can be "forgotten", provided they are in degree of stratification (at least one storage cycle is still required). But the optimu flow-rate cannot be deternined uniess the daily araw-off profile is known. 
Fig.3: Optiman flow-rate ratio for an external heat-exchanger

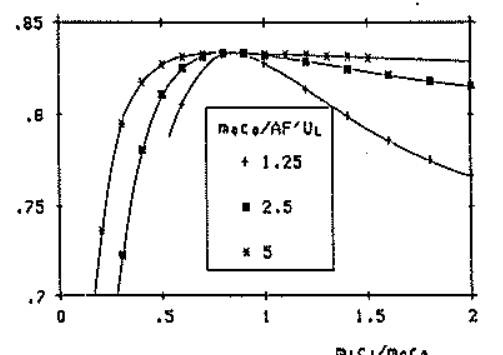

REFERENCES

BOURGES, B., and J.ADNOT (1986). A generalized closed-form model for solar hot water systems. (to be published in SOLAR ENERGY)

DUFFIE, J.A, and W.BECKMAN (1980). Solar Eng. of thermal processes. WILEY.

FANNEY, A.H., and S.A.KLEIN (1986). Thermal performance comparison for solar hot water systems subjected to various collector array flow-rates. INIERSOL $85,538-543$, Pergamon Press.

FETEREISEN, T.J., and co-w. (1982). Heat transfer from immersed coils. ASME 82-WA/Sol-18.

GORDON, J.M., and Y.ZARMI (1981). Thermosyphon systems: single vs multi-pass. SOLAR ENERGY, 27, 441-442.

HOLLANDS, K.G.T., D.R.RICHMOND and D.R.MANDLESTAM (1986). Re-engineering domestic hot water systems for low flow. INIERSOL 85, 544-548, Pergamon Press PHILLIPS, W.F. (1981). Integrated performance of liquid-based solar heating sYstems. SOLAR ENERGX, 26, 287-295.

PHILLIPS, W.F., and R.N.DAVE (1982). Effects of stratification on the performance of liquid-based solar heating systens. SOLAR ENERGY, 29, 111-120.

VAN KOPPEN, C.W.F, and CO-W. (1979). Proceedings ISES biennal meeting, Atlanta, $2,5,5-58$, and comon

(1985). Promising control alternatives for solar water heating systems. ASME J. of Solar Energy Engineering,
107, 215-221.

\section{NOMENCLATURE}

$\mathrm{A}_{\mathrm{e}} \mathrm{U}$ Heat transfer coefficient

$\mathrm{H}_{t}^{\mathrm{e}}$ Daily global irradiation

$\mathrm{m}_{0}^{t}$ Collector flow-rate

mi Heat-exch./storage flow-rate

$\mathrm{m}_{2} \quad$ Draw-off flow-rate

${ }_{\mathrm{T}}^{\mathrm{d}}$ Mains cold water temperature

torage initial temperature 